\title{
Between mandatory and voluntary: non-financial reporting by German companies
}

\author{
Esther Hoffmann ${ }^{1}$ (D) $\cdot$ Christian Dietsche ${ }^{1} \cdot$ Christine Hobelsberger $^{1}$
}

Published online: 14 November 2018

(c) The Author(s) 2018

\begin{abstract}
Non-financial reporting by German companies has long been a voluntary matter. As of fiscal year 2017, the CSR Directive Implementation Act makes it mandatory for some 500 large German companies. This article identifies the trends and developments in voluntary reporting based on an analysis of the quality of sustainability reports published by German companies from 2014 and 2015. The number of stand-alone sustainability reports and integrated reports is increasing and companies are orienting, in particular, on the guidelines provided by the Global Reporting Initiative. We find that there is room for quality improvements. Moreover, we show that many reports from companies that are new to reporting are still incomplete in terms of content. We additionally conduct an analysis of non-financial information presented by 522 German companies during financial year 2015 or 2016 that are now subject to reporting requirements starting with financial year 2017. The study shows that many reports still need further development to meet the requirements of the CSR Directive Implementation Act. Specifically, a more rigorous selection and linking of financial and non-financial information is necessary while other areas for improvement include the descriptions of the policies in use for tracking the relevant matters as well as for handling of risks. The analysis of the current non-financial information also shows that the quality and depth of sustainability-related information is generally greater in stand-alone reports oriented to frameworks such as the GRI4 or the German Sustainability Code than in management reports.
\end{abstract}

For the ranking of sustainability reports we signed a Code of Conduct that can be found at: http://www.rankingnachhaltigkeitsberichte.de/data/ranking/user_upload/pdf/ I\%C3\%96W-future-Ranking_Nachhaltigkeitsberichte_ Verhaltenskodex.pdf

Esther Hoffmann esther.hoffmann@ioew.de

1 Institute for Ecological Economy Research, Potsdamer Str. 105, 10785 Berlin, Germany 


\section{Zwischen Pflicht und Kür: Nichtfinanzielle Berichterstattung deutscher Unternehmen}

\section{Zusammenfassung}

Nichtfinanzielle Berichterstattung war für deutsche Unternehmen lange Zeit freiwillig. Durch das CSR-Richtlinie-Umsetzungsgesetz wird sie ab dem Geschäftsjahr 2017 für etwa 500 große deutsche Unternehmen verpflichtend. Anhand einer Analyse der Qualität von Nachhaltigkeitsberichten deutscher Unternehmen aus den Jahren 2014 und 2015 stellt der Artikel Trends und Entwicklungen bei der freiwilligen Berichterstattung fest. Hier zeigt sich, dass die Anzahl an eigenständigen Nachhaltigkeitsberichten und an integrierten Berichten zunimmt und dass sich Unternehmen bei der Berichterstattung insbesondere an den Leitlinien der Global Reporting Initiative orientieren. Gleichzeitig wird deutlich, dass die Qualität der Berichte verbessert werden könnte und dass viele Berichte von Unternehmen, die neu in die Berichterstattung einsteigen, inhaltlich noch lückenhaft sind. Die Betrachtung von Nachhaltigkeitsberichten wird ergänzt durch eine Analyse von nichtfinanziellen Informationen zum Geschäftsjahr 2016 bei 522 deutschen Unternehmen, die ab dem Geschäftsjahr 2017 unter die Berichtspflicht fallen. Die Untersuchung verdeutlicht, dass viele Unternehmen hinsichtlich der Erfüllung der Anforderungen des CSR-Richtlinie-Umsetzungsgesetzes noch Weiterentwicklungsbedarf haben, zum einen hinsichtlich einer konsequenteren Auswahl und Verknüpfung finanzieller und nichtfinanzieller Angaben, zum anderen mit Blick auf die Beschreibung von angewandten Konzepten zur Verfolgung der berichtspflichtigen Themenfelder sowie von Risiken und deren Handhabung. Die Analyse der bisherigen nichtfinanziellen Informationen zeigt zudem, dass die Qualität und Tiefe nachhaltigkeitsbezogener Informationen in der Regel in eigenständigen, an Rahmenwerken wie dem GRI4 oder dem DNK orientierten Berichten größer ist als in Lageberichten.

\section{Introduction}

Non-financial reporting by German companies has long been a voluntary matter. Since the early 2000s, German companies have published non-financial information mostly as CSR or sustainability reports. Publishing comprehensive non-financial information will be mandatory as of fiscal year 2017 for some large German companies as a result of the CSR Directive Implementation Act. The CSR Directive Implementation Act obliges large companies of public interest, in particular, capital market-oriented companies, credit institutions, and insurance companies to publish nonfinancial information (Deutscher Bundestag 2017). According to one estimate, the new reporting requirement in Germany affects a total of 536 companies, including 278 capital market-oriented companies and 258 non-capital marketoriented credit institutions and insurance companies (Kluge and Sick 2016). While some of these companies already report non-financial information prior to the entry into force of the CSR Directive Implementation Act, many others will be submitting relevant reports for the 2017 financial year in 2018 for the first time.

With respect to mandatory non-financial disclosure, other countries such as Denmark, Norway, Sweden, Australia and the Netherlands all introduced regulations during the 1990s to oblige companies to report annually on their environmental performance. In 2001, France passed a law that required firms to disclose their environmental and social impact, and in 2005, the UK introduced a similar mandate (Hess 2007). In other countries, such as South Africa or China, a disclosure mandate was introduced as a requirement for companies listed on certain stock exchanges (Ioannou and Serafeim 2011). The European Union adopted a directive on non-financial reporting in 2014 (EU Directive 2014/95/EU). In Germany, the corresponding CSR Directive Implementation Act was implemented in autumn 2016.

Prior research has shown that mandatory non-financial disclosure might have a positive impact on the degree of disclosure (e.g. Ioannou and Serafeim 2011). However, there are contradictory results on the question whether mandatory reporting has an influence on reporting quality (Hąbek and Wolniak 2016; Lock and Seele 2016). Moreover, several researchers describe a need for studies on reporting quality and for respective assessment frameworks (e.g. Hahn and Kühnen 2013). To understand changes in reporting quality based on introducing mandatory financial disclosure in Germany it is thus important to identify the current quality of reporting among German companies.

We aim to provide an overview on the quality of reporting in German companies and address the following research questions: What is the current state of non-financial reporting by German companies? What is its scope and quality? How does the upcoming regulation influence nonfinancial reporting in German companies?

To answer these questions, we introduce two studies: One of these is the ranking of sustainability reports regularly prepared by the Institute for Ecological Economy Research (IÖW) and future since 2005. ${ }^{1}$ This ranking aims to compare the sustainability reporting of German companies and to promote quality competition among the reports. The methodology and results of the ranking process for the year 2015 are presented in this article. The second study presents

\footnotetext{
${ }_{1}$ Prior to this, IÖW and future had performed a total of four rankings of environmental reports since 1994.
} 
the methodology and results of an analysis of the non-financial reporting of German companies from the year 2017. The aim of this study was to record the extent to which the German companies that are obligated to report non-financial information on the financial year 2017 may already be in compliance with the requirements of the CSR Directive Implementation Act in their reporting to date.

Our contribution is a baseline of non-financial reporting in Germany before the CSR Directive Implementation Act enters into force and an overview of the current state and development of reporting quality in German companies' sustainability reports. Moreover, we develop research questions and suggestions for future research that describe influencing factors on reporting quality such as reporting experience, reliance on standards or reporting format.

We structure the paper as follows: The next section provides an overview on the German CSR Implementation Act. Sect. 3 includes a literature review presenting insights into changes between mandatory and voluntary reporting and on measuring reporting quality. We then introduce our research methods (Sect. 4) and present the results for the status and quality assessment of sustainability reporting (Sect. 5) and of non-financial reporting (Sect. 6). We finally discuss the results and draw conclusions including suggestions and questions for further research (Sect. 7).

\section{The German csr directive implementation act}

The CSR Directive Implementation Act requires the reporting companies to provide a brief description of the business model and disclosures on non-financial issues such as environmental, social and employee-related matters, respect for human rights, anti-corruption and bribery matters. Although the law cites exemplary sub-topics for each individual topic, it does not provide specific content requirements or other requirements, so the scope, quality, and depth with which the topics are dealt with are left rather open.

Following the CSR Directive Implementation Act's principle of materiality, companies are required to report about non-financial aspects that are relevant for the course of business, the business results and the situation of the company. This materiality definition differs from the one provided by the Global Reporting Initiative (GRI) which forms the basis for most sustainability reports. According to the latter understanding, sustainability related aspects should be reported even though they do not have any direct impact on a company's business operations.

The law requires a description of the policies pursued relative to each topic, including the due diligence processes applied and the outcome of the policies. In case the reporting company does not pursue a policy with regard to an individual topic, it must explain this in a clear and wellfounded manner in the sense of the "comply or explain" principle. Additionally, the law requires a description of major risks, both in terms of the reporting entity's operations, and its business relationships, products, and services. The company further has to describe its measures to handle these risks.

Whereas there is no obligation to externally audit the reported non-financial information, the law does require the release of the results if the non-financial information has been subject to external substantive review. The law allows several variants regarding the form of publication of nonfinancial information: The reporting entity may include its non-financial statement in the management report ${ }^{2}$ or prepare a separate non-financial report to be published in the Federal Gazette ${ }^{3}$ at the same time as the management report. Alternatively, a reporting company has the option of publishing a separate non-financial report on their website.

Today, there are numerous principles, guidelines, and frameworks for the publication of non-financial information (e.g., German Council for Sustainable Development 2017; Global Reporting Initiative 2013, 2016; International Integrated Reporting Council 2013; UN Global Compact 2012; Verein zur Förderung der Gemeinwohl-Ökonomie 2015), all of which formulate requirements and assist in improving the quality of the reports. Key in this area are the guidelines of the Global Reporting Initiative (GRI), which were developed as part of a multi-stakeholder process and first published in 2000 (GRI 2000) and since that time have been continuously further developed. If a framework is used for the preparation of the non-financial statement, it is legally required to indicate within the report which framework was applied. Otherwise, it must be justified why no framework was used for the report.

\section{Literature review}

A handful of studies have analyzed the effects caused by introducing mandatory reporting. Bubna-Litic (2004) explores how a change in Australia's Corporations Law in 1998 affected the top 100 companies, which were obliged to report on their environmental performance. She finds that

\footnotetext{
2 The management report embodies a legally and functionally independent accounting tool for companies to meet their reporting duties in addition to the annual financial statements. It can be used to explain the financial statements and supplement them with general information about the course of business including the business results and the situation of the company. (Springer Gabler Verlag n.d., n.p.).

3 The Federal Gazzette is the central platform for official proclamations and announcements as well as for legally relevant corporate news in the Federal Republic of Germany (Federal Ministry of Justice and Consumer Protection 2018, n.p.).
} 
within three years, the share of firms that reported on environmental issues increased considerably. Chen et al. (2018) investigate the effect of a disclosure mandate introduced for certain firms listed on the Shanghai Stock Exchange and the Shenzhen Stock Exchange in 2008 by comparing their performance before and after the introduction of the mandate. Comparing the firms that face a disclosure mandate with a control group, they conclude that the mandate reduces firm profitability. However, they also report improvements in environmental performance. Ioannou and Serafeim (2011) apply the same approach to a data set based on China as well as Denmark, South Africa and Malaysia where nonfinancial disclosure became mandatory for some firms in 2009, 2010 and 2008 respectively. Using environmental, social and corporate governance (ESG) reporting data from Bloomberg, they find that compared to the control groups, firms facing a disclosure mandate were significantly more likely to disclose non-financial information, to receive external assurance and to adopt reporting guidelines. Using the same quasi-natural experiment, Boodoo (2016) gathers ESG data on the 100 Indian firms listed on the Bombay Stock Exchange for which stand-alone CSR reports became mandatory at the beginning of 2013. He finds that the announcement of mandatory ESG disclosure improved performance regarding environmental, social and governance aspects respectively.

Other researchers have analyzed whether reporting quality varies between mandatory and voluntary reporting. Lock and Seele (2016) conduct a quantitative content analysis of 237 CSR reports published before summer 2014 by European firms. They compare the credibility of CSR reporting in countries with and without legally mandated disclosure and find no significant difference. In contrast to their results, Hąbek and Wolniak (2016) assess the CSR disclosure quality of 507 firms in several European countries and find that firms that face a disclosure mandate achieve significantly higher reporting quality scores.

In conclusion, the literature on differences between mandatory and voluntary reporting shows a variety of results indicating positive effects on the number of reports, the degree of disclosure and on environmental respectively ESG performance and in one study negative impacts on profitability. Regarding reporting quality, the results are contradictory. With our article, we aim at addressing these unclear findings regarding report quality and look whether the (upcoming) mandatory reporting already shows an impact on scope and quality of reporting.

Researchers have developed various methods to assess the quality of sustainability reports but up until now, no established standard has emerged. Table 1 provides an overview on different studies.

Most of the approaches are based on different criteria or indicators that are grouped to different categories. The amount of categories varies between 2 (Hąbek and Wolniak 2016) and 6 (Bouten et al. 2011), and of indicators between 17 (Hąbek and Wolniak 2016) and 96 (Lock and Seele 2016). Many researchers have developed these criteria based on the GRI framework (e.g. Bouten et al. 2011; Romolini et al. 2014), others base their analysis on theoretical concepts (e.g. Lock and Seele 2016 who develop their criteria based on Habermas' communicative action theory) or analytical frameworks (e.g. Michelon et al. 2015). Most of them assign points for each criterion and use scales with different rates to achieve an overall quality assessment, others only check the presence of certain topics (e.g. Bouten et al. 2011; Romolini et al. 2014). While some researchers use equal weights for all criteria (e.g. Hąbek and Wolniak 2016), others include factors to weigh in order to account for the importance of certain criteria (e. g. Daub 2007). Most approaches include content factors and aspects of communicative quality, others only assess the content (e.g. Bouten et al. 2011; Romolini et al. 2014). Almost all analyses are conducted at a certain point of time and do not provide comparisons between different years, exceptions are Daub (2007) who conducted his analysis in 2003 and 2004 as well as Romolini et al. (2014) who compare their sample from the years 2008 to 2010. Most of the analyses only include large companies and their sustainability or annual reports, Hąbek and Wolniak's (2016) sample contains some small and medium enterprises from Sweden.

Most of the studies aim at measuring or describing reporting quality, some analyze influencing factors for reporting quality (e.g. Lock and Seele 2016; Michelon et al. 2015). In a nutshell, the studies show that there is a large variety among reports and that there is still a considerable need for improvements.

Overall, several researchers indicate that there is a need for more robust and widely applicable assessment frameworks to benchmark the quality of sustainability reports (Hahn and Kühnen 2013; Morhardt 2001; Skouloudis et al. 2009). Our study would like to contribute to this by presenting a framework to assess the quality of sustainability reports that is applicable for SMEs and large corporations and that can be used for repeated assessments and longterm comparisons.

\section{Methods}

\subsection{Ranking sustainability reports}

The sustainability report ranking is an evaluation of sustainability and CSR or comparable reports (e.g., integrated reports) published by German companies. The ninth overall ranking took place in 2015. Since 2009, we have carried out two separate analyses, one for large companies and one 
Table 1 Overview of studies on sustainability reporting quality

\begin{tabular}{|c|c|c|c|c|c|c|}
\hline Author(s) Year & Categories & $\begin{array}{l}\text { Number of } \\
\text { criteria }\end{array}$ & Assessment & $\begin{array}{l}\text { Analyzed } \\
\text { countries }\end{array}$ & Analyzed reports & Results \\
\hline Daub (2007) & $\begin{array}{l}\text { a) Context and cov- } \\
\text { erage } \\
\text { b) policies, man- } \\
\text { agement systems } \\
\text { and stakeholder } \\
\text { relations } \\
\text { c) dimensions of } \\
\text { performance } \\
\text { d) transparency and } \\
\text { general view }\end{array}$ & 33 & $\begin{array}{l}\text { Between } 0 \\
\text { and } 3 \text { points } \\
\text { for each crite- } \\
\text { rion }\end{array}$ & Switzerland & $\begin{array}{l}\text { Annual and other } \\
\text { periodically pub- } \\
\text { lished reports } \\
\text { (sustainability, } \\
\text { environmental, } \\
\text { social) from the } \\
\text { top } 100 \text { Swiss } \\
\text { companies based } \\
\text { on turnover, } \\
124 \text { reports by } \\
76 \text { participating } \\
\text { companies were } \\
\text { evaluated }\end{array}$ & $\begin{array}{l}\text { Companies are } \\
\text { ranked from } \\
\text { No. } 1 \text { to No. } 76 \\
\text { according to } \\
\text { their total crite- } \\
\text { ria scoring; all } \\
\text { companies com- } \\
\text { bined attained } \\
\text { an average score } \\
\text { of one third of } \\
\text { points possible } \\
\text { highlighting the } \\
\text { necessity for } \\
\text { further improve- } \\
\text { ments in terms of } \\
\text { reporting quality }\end{array}$ \\
\hline $\begin{array}{l}\text { Hąbek and Wol- } \\
\text { niak (2016) }\end{array}$ & $\begin{array}{l}\text { a) Information rele- } \\
\text { vance } \\
\text { b) credibility }\end{array}$ & 17 & $\begin{array}{l}\text { Each criterion } \\
\text { is rated on } \\
\text { a scale from } \\
0 \text { to } 4 \text { and } \\
\text { is weighted } \\
\text { equally }\end{array}$ & $\begin{array}{l}\text { Denmark, } \\
\text { Sweden, } \\
\text { France, } \\
\text { Poland, the } \\
\text { Netherlands } \\
\text { and the UK }\end{array}$ & $\begin{array}{l}507 \text { sustainability } \\
\text { reports }\end{array}$ & $\begin{array}{l}\text { Reporting quality } \\
\text { is low with room } \\
\text { for improvement } \\
\text { in every country, } \\
\text { relevance is on } \\
\text { a higher level } \\
\text { than credibility }\end{array}$ \\
\hline $\begin{array}{l}\text { Lock and Seele } \\
\text { (2016) }\end{array}$ & $\begin{array}{l}\text { Credibility as the } \\
\text { mean of the four } \\
\text { constructs: } \\
\text { a) Truth } \\
\text { b) Sincerity } \\
\text { c) Appropriateness } \\
\text { d) Understandability }\end{array}$ & $\begin{array}{l}96 \text { (grouped in } \\
\text { formal, con- } \\
\text { tent and GRI } \\
\text { Indicators) }\end{array}$ & $\begin{array}{l}\text { Quantitative } \\
\text { content analy- } \\
\text { sis with open, } \\
\text { nominal and } \\
\text { ordinal codes } \\
\text { as well as } \\
\text { scales from } \\
0-3 \text { or } 0-10 \\
\text { for the GRI } \\
\text { indicators }\end{array}$ & $\begin{array}{l}\text { Strongest } \\
\text { European } \\
\text { economies by } \\
\text { GDP: Aus- } \\
\text { tria, Belgium, } \\
\text { France, Ger- } \\
\text { many, Italy, } \\
\text { Netherlands, } \\
\text { Poland, Spain, } \\
\text { Sweden, } \\
\text { Switzerland, } \\
\text { UK }\end{array}$ & $\begin{array}{l}237 \text { sustainability } \\
\text { reports retrieved } \\
\text { from companies } \\
\text { that are listed } \\
\text { in stock market } \\
\text { indices of the } \\
\text { analyzed coun- } \\
\text { tries (e.g. DAX } \\
\text { in Germany) }\end{array}$ & $\begin{array}{l}\text { Assessed reports } \\
\text { are mediocre } \\
\text { rather than good } \\
\text { in terms of cred- } \\
\text { ibility, leaving } \\
\text { room for im- } \\
\text { provement }\end{array}$ \\
\hline $\begin{array}{l}\text { Bouten et al. } \\
\text { (2011) }\end{array}$ & $\begin{array}{l}\text { Six CSR areas with } \\
\text { respective sub- } \\
\text { items: } \\
\text { a) Economic } \\
\text { b) Environment } \\
\text { c) Human Rights } \\
\text { d) Labor practices } \\
\text { and decent work } \\
\text { e) Product responsi- } \\
\text { bility } \\
\text { f) Society }\end{array}$ & $\begin{array}{l}3 \text { for each sub- } \\
\text { item (vision } \\
\text { and goals, } \\
\text { management } \\
\text { approach and } \\
\text { performance } \\
\text { indicators) }\end{array}$ & $\begin{array}{l}\text { Presence of } \\
\text { criteria }\end{array}$ & Belgium & $\begin{array}{l}\text { Annual reports } \\
\text { of } 108 \text { listed } \\
\text { companies }\end{array}$ & $\begin{array}{l}\text { The level of com- } \\
\text { prehensive re- } \\
\text { porting on vision, } \\
\text { management } \\
\text { approach and } \\
\text { performance in- } \\
\text { dicators for sub- } \\
\text { items is low }\end{array}$ \\
\hline $\begin{array}{l}\text { Michelon et al. } \\
(2015)\end{array}$ & $\begin{array}{l}\text { a) Content of the in- } \\
\text { formation disclosed } \\
\text { b) type of measures } \\
\text { used to describe } \\
\text { and discuss CSR } \\
\text { activities } \\
\text { c) managerial orien- } \\
\text { tation }\end{array}$ & $\begin{array}{l}32 \text { codes for } \\
\text { content, } 3 \\
\text { for types of } \\
\text { measures and } 4 \\
\text { for managerial } \\
\text { orientation }\end{array}$ & $\begin{array}{l}\text { Indices rang- } \\
\text { ing between } \\
0 \text { and } 1 \text { based } \\
\text { on formulas }\end{array}$ & UK & $\begin{array}{l}\text { Sustainability } \\
\text { reports or sustain- } \\
\text { ability section in } \\
\text { annual reports of } \\
112 \text { companies } \\
\text { from the London } \\
\text { Stock Exchange }\end{array}$ & $\begin{array}{l}\text { Sustainability } \\
\text { reporting is sym- } \\
\text { bolic rather than } \\
\text { substantive. Prac- } \\
\text { tices such as } \\
\text { stand-alone re- } \\
\text { ports, assurance } \\
\text { and reporting } \\
\text { guidance are not } \\
\text { associated with } \\
\text { higher quality of } \\
\text { disclosure }\end{array}$ \\
\hline
\end{tabular}


Table 1 (Continued)

\begin{tabular}{|c|c|c|c|c|c|c|}
\hline Author(s) Year & Categories & $\begin{array}{l}\text { Number of } \\
\text { criteria }\end{array}$ & Assessment & $\begin{array}{l}\text { Analyzed } \\
\text { countries }\end{array}$ & Analyzed reports & Results \\
\hline $\begin{array}{l}\text { Romolini et al. } \\
\text { (2014) }\end{array}$ & $\begin{array}{l}\text { Following GRI3.0: } \\
\text { a) Economic } \\
\text { b) Environmental } \\
\text { c) Social }\end{array}$ & $\begin{array}{l}79 \text { based on } \\
\text { GRI3.0 indica- } \\
\text { tors }\end{array}$ & $\begin{array}{l}\text { Frequency } \\
\text { of indicators } \\
\text { used over } \\
\text { the course of } \\
\text { three years }\end{array}$ & Italy & $\begin{array}{l}\text { Sustainability, } \\
\text { social and envi- } \\
\text { ronmental reports } \\
\text { as well as code } \\
\text { of ethics from } \\
23 \text { companies } \\
\text { that are part of } \\
\text { the FTSE ECPI } \\
\text { Leaders Index of } \\
\text { the Italian Stock } \\
\text { Exchange }\end{array}$ & $\begin{array}{l}\text { Good level of } \\
\text { disclosure from } \\
\text { Italian companies } \\
\text { that are consid- } \\
\text { ered as leaders } \\
\text { according to } \\
\text { the FTSE ECPI } \\
\text { Leaders Index }\end{array}$ \\
\hline
\end{tabular}

for small and medium-sized enterprises. The large company ranking looks at the reports of the $150^{4}$ largest German industrial and service companies. ${ }^{5}$ The SME ranking includes only reports voluntarily submitted to us for evaluation from companies that employ up to 5000 people or generate annual sales of up to 500 million euros.

The assessments took place from January to June 2016. We considered all reports published by January 22, 2016 in the large company assessment (a total of $79^{6}$ reports). Most of the reports covered the financial year 2014 and some of them reported on 2015. Three quarters of the large companies will be subject to the upcoming reporting requirements in the CSR Directive Implementation Act; only 19 companies are not obligated to report.

The last possible submission date for SME reports was February 15, 2016. 62 SMEs submitted reports for the ranking. After a qualitative screening, we selected 40 reports for evaluation. The selected reports dealt with different financial years: a few reported on 2012, some on 2013, the majority on 2014 and some on 2015. Only six of the SMEs represented in the ranking will be subject to obligatory reporting.

The reports of large companies and SMEs were systematically evaluated on the basis of separate sets of criteria (cf.

\footnotetext{
${ }^{4}$ The selection is based on the list of the top 250 companies as released by the Frankfurter Allgemeine Zeitung (FAZ). The list includes: a) 100 largest industrial companies and service providers, in terms of turnover, b) 15 largest banks in terms of total assets, c) 15 largest insurance companies measured by total premiums, d) 20 largest retailers, in terms of turnover.

${ }^{5}$ Seven other companies whose sales figures were somewhat lower were also included because they have long been voluntary reporters and have often proven to set the example for reporting in their sectors.

${ }^{6}$ Including the seven companies mentioned in footnote 5 .
}

Table 2 and IÖW and future 2015a, 2015b). ${ }^{7}$ The criteria are classified into material requirements as well as requirements for general report quality. The material reporting requirements include economic and management aspects as well as social and environmental factors in production, products and services, as well as in the supply chain and societal relationships. The requirements criteria for general report quality include good practices such as materiality, credibility, comparability and communicative quality.

We used twelve main criteria for the evaluation of the sustainability reports, with each being further specified in individual sub-criteria. The criteria set for large companies consisted of 48 individual criteria. The generally formulated criteria for major corporations were also supplemented by sector-specific specifications. The evaluation of the SME reports applied 26 individual criteria. The SME criteria are more general in nature to account for the wide range of SMEs involved-from micro companies to large SMEs with several thousand employees-and the sometimes very individual approaches to sustainability reporting, and in consideration of the more limited SME resources. For example, the ability to influence the supply chain is much lower for SMEs than for a major corporation.

A maximum of five points can be achieved for each individual criterion. Points are awarded as follows:

- 5 Points $=$ Formulated requirements are fully met

- 3 Points $=$ Formulated requirements are largely met.

- 1 Point = Formulated requirements are met only to a limited extent.

- 0 Point $=$ Not presented/no information available.

\footnotetext{
7 To incorporate current developments at the national and international levels in the field of sustainability reporting, the evaluation criteria of the ranking are regularly revised for each iteration. The current ranking is based on the evaluation criteria as of December IÖW and future (IÖW/future 2015a, 2015b). A workshop with representatives of the businesses and civic communities was organized to discuss the draft of the criteria and provide feedback for the final revision.
} 
Table 2 Criteria set for ranking sustainability reports (IÖW and future 2016, p. 8)

\begin{tabular}{|c|c|c|c|c|}
\hline \multirow[t]{2}{*}{ Ranking criteria } & \multicolumn{2}{|l|}{ SME } & \multicolumn{2}{|l|}{ Large Company } \\
\hline & No. of criteria & Max. score & No. of criteria & Max. score \\
\hline \multicolumn{5}{|l|}{ A Material reporting requirements } \\
\hline A.1 Company profile & 1 & 25 & 3 & 25 \\
\hline $\begin{array}{l}\text { A. } 2 \text { Vision, strategy, and manage- } \\
\text { ment }\end{array}$ & 3 & 100 & 4 & 100 \\
\hline A. 3 Targets and program & 2 & 75 & 2 & 75 \\
\hline A.4 Employee interests & 6 & 75 & 8 & 75 \\
\hline $\begin{array}{l}\text { A. } 5 \text { Environmental aspects in } \\
\text { production }\end{array}$ & 5 & 75 & 8 & 75 \\
\hline A.6 Product responsibility & 3 & 100 & 3 & 100 \\
\hline A.7 Supply chain responsibility & 1 & 50 & 3 & 100 \\
\hline A.8 Societal responsibility & 1 & 50 & 4 & 50 \\
\hline \multicolumn{5}{|l|}{ B General report quality } \\
\hline B.1 Credibility & 1 & 50 & 3 & 25 \\
\hline B.2 Materiality & 1 & 50 & 1 & 25 \\
\hline B.3 Compararbility & 1 & 25 & 3 & 25 \\
\hline B.4 Quality of communication & 1 & 25 & 6 & 25 \\
\hline Total & 26 & 700 & 48 & 700 \\
\hline
\end{tabular}

The steps between 1, 3, or 5 points sometimes have criteria-specific definitions (IÖW and future 2015a, 2015b). Depending on the degree of relevance, criteria are weighted differently and summed to a maximal score of 700 points (see Table 2 for details).

The actual evaluation process consists of several phases. We document the criteria-related references and assessments in a detailed evaluation form for each company. We conduct an internal quality review of these forms. Subsequently each company receives its evaluation and the companies have the possibility to provide feedback, pointing out in writing any misunderstandings or information that was not taken into account. As part of the evaluation process, around $70 \%$ of companies took the opportunity to provide feedback on their evaluation form. Based on this feedback, the assessments are re-examined and, if necessary, adjusted and subjected to further internal quality assurance. At the conclusion of the evaluation process, the ranking is created and individual assessments are made for each criterion.

\subsection{Analysis of non-financial reporting by German companies}

Although the requirements of the CSR Directive Implementation Act have to be met for the first time for financial year 2017 , some companies already provided non-financial information for financial year 2016. The reporting activities were reviewed and subjected to a qualitative assessment. This assessment aims at determining whether and if so, in what form and to what extent, companies already disclose non-financial information as required by the CSR Directive Implementation Act.
For the analysis, we used the current non-financial reports of 522 companies subject to upcoming reporting requirements (see Kluge and Sick 2016), which were already available on June 30, 2017 either in the Federal Gazette or on the website of the company in question. In the event a company did not publish a stand-alone non-financial report or integrate a non-financial statement in their management report, we evaluated the company's management report. The period covered by the reports is in some cases the business year 2015, and in most reports 2016.

We developed a tool for the qualitative assessment of the reports (IÖW and future 2018). In addition to general data such as the industry affiliation of the company or the type of report available, the tool captures the (minimum) content for non-financial reporting required by the CSR Directive Implementation Act. Table 3 shows the criteria and key questions of the study.

\section{Status and quality of sustainability reporting}

This section presents the ranking results for the sustainability reports for the year 2015 and some comparisons with the results from previous years. We focus, in particular, on the reporting trends identified.

\subsection{Increasing number of sustainability reports}

The number of reporting companies has increased since the 2011 ranking. At that time, there were 56 stand-alone sustainability reports published by the 150 largest German 
Table 3 Criteria and key questions for the analysis of non-financial information (IÖW and future 2018, p. 13)

\begin{tabular}{|c|c|c|}
\hline \multicolumn{2}{|c|}{ Criteria } & \multirow{2}{*}{$\begin{array}{l}\text { Key questions } \\
\text { Is there a compact presentation of the business model? }\end{array}$} \\
\hline A & Description of the business model & \\
\hline \multirow[t]{2}{*}{ B } & \multirow[t]{2}{*}{ Policies, due-diligence processes, outcomes of the policies } & $\begin{array}{l}\text { Are policies, the due-diligence process, and their outcomes } \\
\text { (comprehensively) described? }\end{array}$ \\
\hline & & Were omissions of individual or multiple aspects explained? \\
\hline B1 & Environmental matters & - \\
\hline B2 & Employee-related matters & - \\
\hline B3 & Social matters & - \\
\hline B4 & Respect for human rights & - \\
\hline B5 & Anti-corruption and bribery matters & - \\
\hline $\mathrm{C}$ & $\begin{array}{l}\text { Risk resulting from business operations } \\
\text { (incl. risk management) }\end{array}$ & $\begin{array}{l}\text { Are the risks related to business operations as well as the } \\
\text { management of these risks (comprehensively) described for } \\
\text { these matters? }\end{array}$ \\
\hline $\mathrm{C} 1$ & Environmental matters & - \\
\hline $\mathrm{C} 2$ & Employee-related matters & - \\
\hline $\mathrm{C} 3$ & Social matters & - \\
\hline $\mathrm{C} 4$ & Respect for human rights & - \\
\hline C5 & Anti-corruption and bribery matters & - \\
\hline $\mathrm{D}$ & $\begin{array}{l}\text { Risk resulting from business relationship, } \\
\text { products and services } \\
\text { (incl. risk management) }\end{array}$ & $\begin{array}{l}\text { Are the risks related to business relationships, products, and } \\
\text { services as well as the management of these risks (compre- } \\
\text { hensively) described for these matters? }\end{array}$ \\
\hline D1 & Environmental matters & - \\
\hline D2 & Employee-related matters & - \\
\hline D3 & Social matters & - \\
\hline D4 & Respect for human rights & - \\
\hline D5 & Anti-corruption and Bribery matters & - \\
\hline $\mathrm{E}$ & Use of frameworks & Was a framework used to prepare the report? \\
\hline $\mathrm{F}$ & External audit of non-financial information & Is non-financial information subject to an external audit? \\
\hline
\end{tabular}

companies and 127 reports from SMEs (IÖW and future 2012a, 2012b). The figures for 2015 are significantly higher, reflecting 72 reports from large companies ${ }^{8}$ (as of: January 2016) and 165 from SMEs (as of: February 2016). This is a clear increase compared to the previous rankings: in the years $2005,2007,2009$, and 2011, the number of sustainability reports fluctuated between 53 and 56 of the 150 largest German companies. Consequently, a number of new reporters are among the companies included in the ranking for 2015 that had not yet published stand-alone reports in 2011.

The number of companies that provide their stakeholders with information on sustainability issues in other ways, (e.g., reports from the parent company, in special brochures, on websites, or in the annual report) also increased. Fig. 1 shows a listing of the 150 largest German companies broken down by category, which identifies the form and intensity of the reporting.

However, the trend does not hide the fact that there are still a number of companies that do not publish sufficient information (if any at all) about their social and environmental

${ }^{8}$ Not including the seven companies mentioned in footnote 5 . impact. Of the 150 largest German companies, 17 publish only some minimal information about sustainability issues and five publish none at all. ${ }^{9}$ The highest proportion of these non-reporting companies is found in the food, media/ information services, insurance, and trade/clothing sectors.

\subsection{Report quality improving at SMEs, dropping at large companies}

The overall report quality for large companies as determined by the ranking is declining. The average rating of all reports dropped from 353 points in 2011 to 311 points. One of the main explanations for this is the high number of new reporters, who often still present an incomplete database and who leave gaps in some topics or provide little meaningful information. Only six of the 22 new reporting companies added since 2011 are among the top 50. The highest ranked newcomer achieved 19th place.

\footnotetext{
9 The number of non-reporters has fallen significantly compared to 2011: At that time, there were still 29 companies with only a little information and 12 without any information (IÖW and future 2012a).
} 
Fig. 1 Classification for nonfinancial information of the 150 largest German companies (number of companies per category, $N=150$, as of: January 2016) (IÖW and future 2017, p. 18)

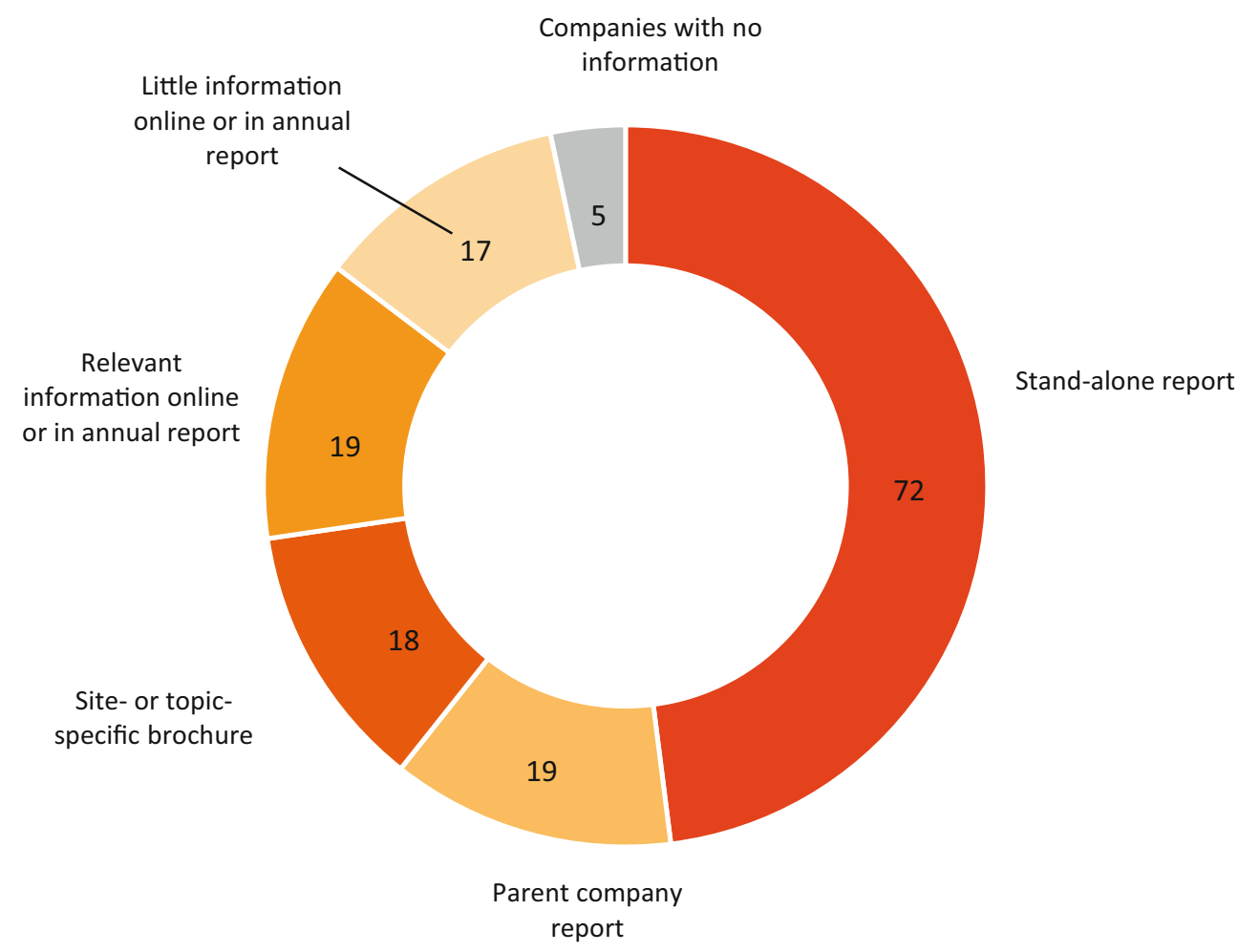

Among long-standing reporters already ranked in 2011, there was only a slight downward trend. These companies achieved an average of 337 points in the 2015 ranking. Some large companies were able to roughly maintain their 2011 results. Others were able to significantly improve by expanding their report coverage. In contrast, there were also some reports that could not live up to their 2011 level in this ranking. One reason for this is the selective tightening of the ranking requirements (for example, regarding supply chain responsibility), but also, some companies reduced the scope and depth of their reporting on sustainability aspects.

Fig. 2 shows how well the reports of large companies meet the main ranking criteria. Roughly half the companies fully or mostly met the requirements in the areas of "Vision, strategy, and management". Many reporters succeeded in explaining the megatrends and general conditions affecting corporate activity and derived priorities for their sustainability strategy and, in a second step, concrete objectives and measures. These companies often show a very systematic approach and base their strategy process on a materiality analysis. Nearly $40 \%$ fully or mostly meet the main criteria "Objectives and programs" and "Societal responsibility." Large company evaluations were much worse in the other criteria. This refers, in particular, to the "Supply chain responsibility" that is satisfactorily met by only half of the reporters. The descriptions of the supply chains in terms of the most important procurements and the regional allocation of the prime suppliers reveal considerable gaps. Moreover, the reports can hardly convey any systematic determination of the environmental, social, or human rights risks in the supply chains. The presentations fare somewhat better in describing environmental, human rights, labor and social standards, for example, those defined in codes of conduct for suppliers. So far, the systems for implementation and review of these requirements are identifiable only in rudimentary form and are not adequately documented by complete figures, such as with supplier audits and their results.

Another trend was identified among SMEs: compared with 2011, they manage to achieve a significant improvement in average values in almost all criteria. Many SMEs have expanded and professionalized their reporting over the last few years so that their reports can now compare to those of large companies in term of scope and quality. The newcomers also have a more positive assessment than those among the large corporations. But, on average, the new reporting companies fare significantly poorer than the established reporters. However, some of them have already ideally implemented the ranking requirements in their first sustainability report.

Fig. 3 shows how well SMEs meet the top ranking criteria. Again, it is the requirements in the areas of "Vision, strategy, management", and "Societal responsibility" that are best met. In terms of vision and strategy, some SMEs present convincing individual approaches, for example, by highlighting their sustainability vision against the background of the company's history and by explaining their specific approaches and strategies for sustainable action. 


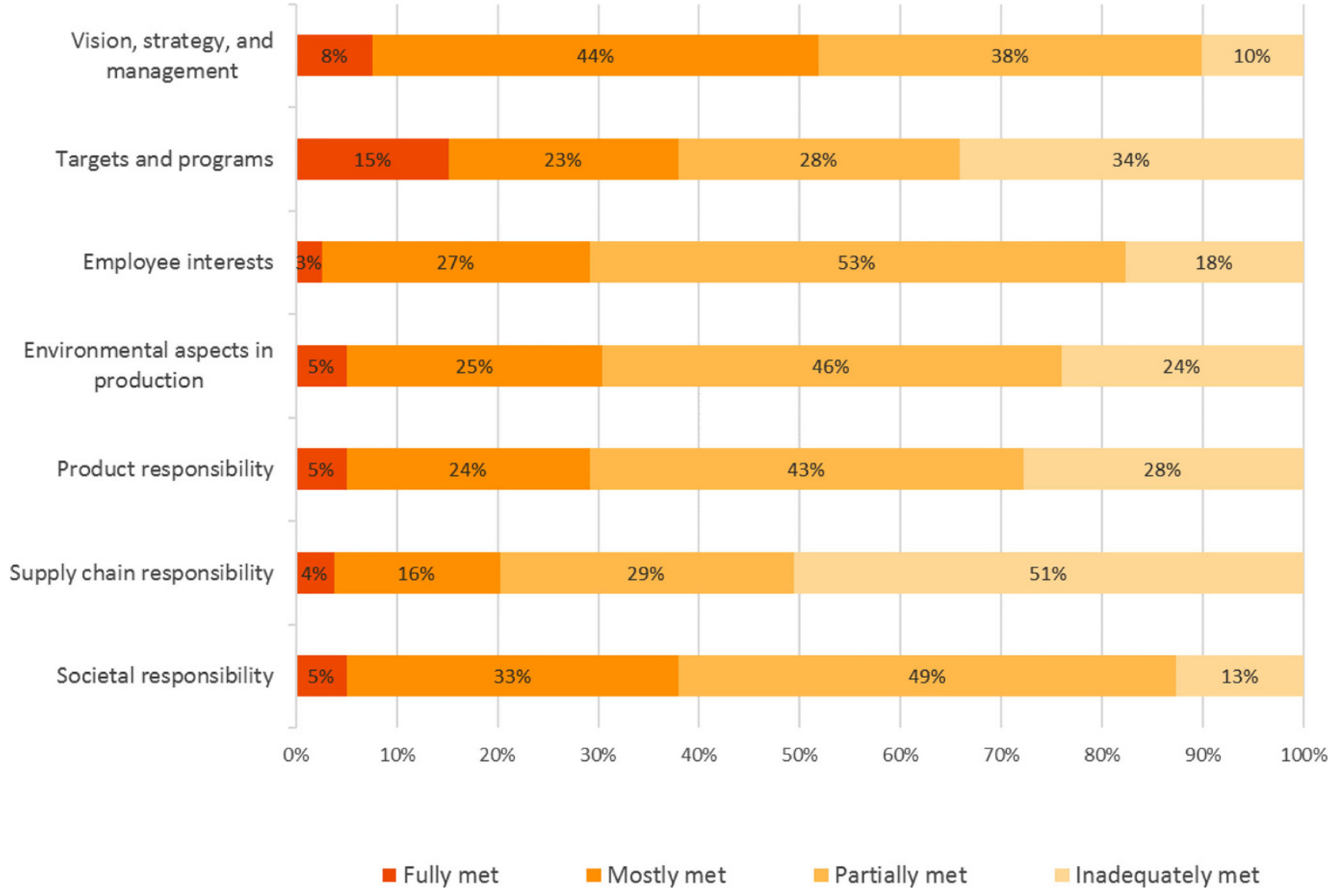

Fig. 2 How well do large company reports meet the main criteria? (Share in \%) $(N=79)$ (A maximum of 5 points can be awarded for each toplevel criterion. The degree of fulfillment is determined by a four-point scale: "Inadequately met" (0 to 1.24 points), "Partially met" (1.25 to 2.49 points), "Mostly met" (2.5 to 3.74 points) and "Fully met" (3.75 to 5 points). Deviations from $100 \%$ are caused by rounding errors.) (IÖW and future 2016, p. 24)

The weakest results by the SMEs are seen in the main criterion, "Employee interests." Specifically, weaknesses are found in the reporting on diversity, working time models and temporary workers.

\subsection{Many reports focus on materiality}

Companies are increasingly focusing their reports on material issues identified on the basis of a materiality analysis: it has become standard practice at most large companies to evaluate the relevance of sustainability aspects from a corporate and stakeholder perspective to derive the priorities for reporting. The exact process for identifying and prioritizing key issues, however, is often not made sufficiently transparent. Most reports now include a materiality matrix that highlights the importance of sustainability issues for the company and its stakeholders.

This trend is also recognizable among SMEs. For many years, the orientation of SME reporting focused primarily on their actual activities and performance: only a few exceptions systematically derive report contents and the main sustainability topics. This is increasingly changing: Many SMEs are now systematically approaching the definition of priority topics and present the results, for example, in the form of a materiality matrix. SMEs also increasingly capture stakeholder expectations and include them in the process.

There appears to be a significant streamlining of the report content by some long-time reporters, especially, among the large corporations. Reporting of the sustainability aspects, which are material from the company's point of view, remains stable or is even expanding among the long-standing reporters, while their presentation of other topics seem to be losing scope and depth. In the context of the "comply or explain" principle, often the explanations as to why individual topics are omitted are hardly meaningful or are even entirely missing.

\subsection{Format variety still increasing}

The traditional printed report is becoming less significant as the leading document for sustainability reporting. Al- 


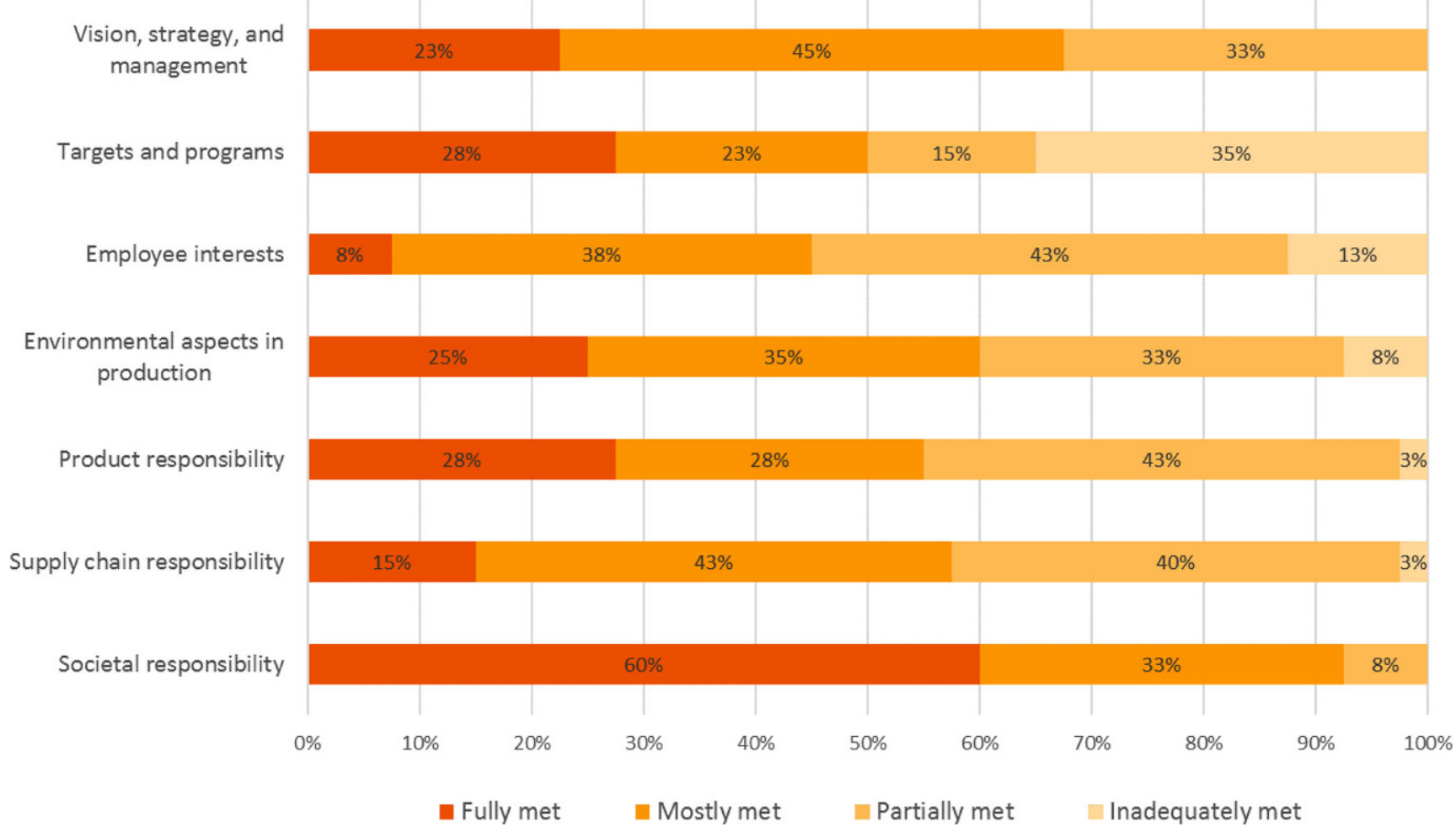

Fig. 3 How well do the reports of SMEs meet the main criteria? (as a percentage) $(N=40)$ (IÖW and future 2016, p. 25) (See Footnotes for Fig. 2.)

though the majority of the companies in the ranking still publish a printed sustainability report, this is often just one of several media, especially, among large companies.

When printed reports are published, they are usually supplemented by extensive online information. 28 of the large companies in the ranking are now publishing online sustainability reports. Some of them additionally offer a PDF version on their websites, while others publish their own PDF or print report in addition to the online report. PDF reports with interactive features are increasingly popular. These offer the possibility to navigate within the report and to immediately select internal cross-references and online links.

The change in the reporting formats is noted, in particular, among the advanced reporters: Among the Top 10 large companies in the ranking, only one still relies on a single print report. In contrast, the reporting by SMEs remains largely centered on the printed sustainability report. But, five of the 40 companies evaluated publish online reports.

A target group-specific differentiation is also noted in the reports. We find platform concepts consisting, for instance, of a corporate responsibility (CR) journal, a GRI report, and a $\mathrm{CR}$ online journal with an interactive key performance indicator tool.

\subsection{A growing number of integrated reports}

The number of integrated reports has increased significantly in large companies compared to 2011. While there were only five in 2011 , in the 2015 ranking there were 16 integrated reports. The trend is particularly evident in the chemical and transport/logistics/tourism sectors. The number of evaluated integrated reports in the SME ranking is much lower and currently totals three, all from energy companies.

Unlike in 2011, when an integrated report placed third in the ranking, the integrated reports in 2015 scored mostly below average in the ranking of large companies. The best ranking among the integrated reports was rank 14. Many integrated reports can only partially complete the range of the ranking requirements. The integrated reports usually have less space available for the presentation of sustainability aspects. In some cases, this leads to a stronger focus on the material aspects of sustainability, as the less relevant aspects are partly eliminated. However, the portrayals of material aspects such as product and supply chain responsibility often lost scope and substance with the transition to integrated reporting. Most reports do not exploit the special potential of the integrated reports: rarely do these reports truly mirror an integrated approach at the companies. For example, this is evident in the predominantly weak presentations of the 
Fig. 4 Distribution of the report forms $(N=522)$

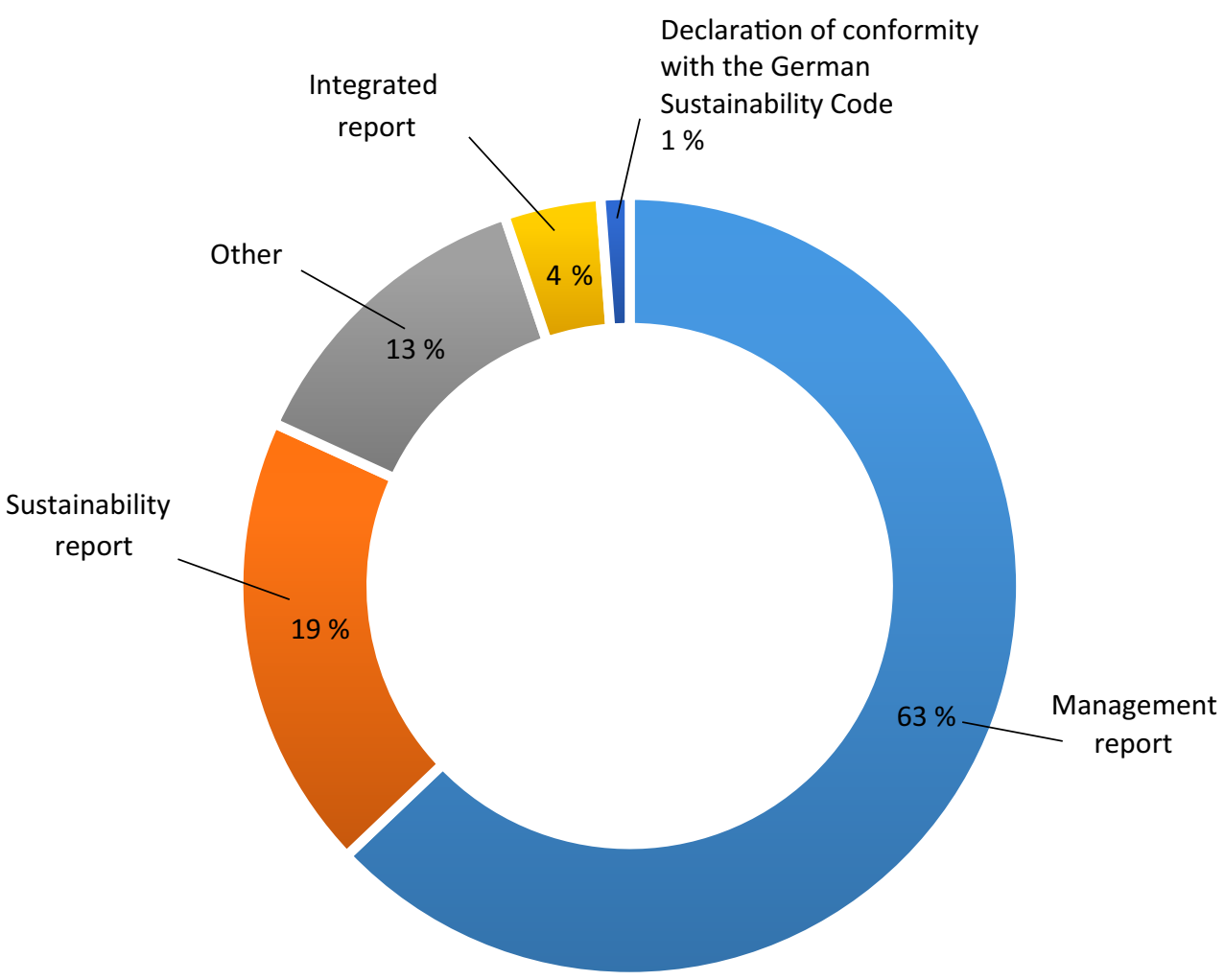

organizational and strategic anchoring of sustainability in the company.

In all fairness, the lack of completeness is sometimes accompanied by greater data reliability and, in return, a particularly high degree of credibility: While in most cases, an external audit of the base data can only provide limited assurance, five of the integrated reporters were able to achieve reasonable assurance.

In practice, the concrete implementation of integrated reporting is varied between companies. The framework set by the International Integrated Reporting Committee (IIRC) in 2013 offers a recognized standard, but only a few of the ranked companies refer to this in their reporting.

\subsection{Importance of GRI guidelines continues to grow}

The Global Reporting Initiative (GRI) guidelines have become established as the standard for reporting among the large German companies. Of the large companies surveyed in the 2015 ranking, 68 reported based on GRI, 32 on G3, and 36 according to the G4 guidelines published in 2013 . The overwhelming majority of G4 users chose to follow "Core" option. Interestingly, only six of the large companies opted for the more sophisticated application level "Comprehensive", which requires that all material aspects and indicators be reported according to the "comply or explain" principle.
The share of GRI reporters in the large corporations has risen again slightly to $86 \%$, up from $83 \%$ in 2011 . Striking is the fact that the top 50 large companies in the ranking without exception all report in accordance with the GRI guidelines. The significance of the GRI guidelines is also increasing among SMEs. Overall, 28 SMEs reported according to the GRI. Of these enterprises, 18 are already applying the newer G4 guidelines, three of which are using the "Comprehensive" option. Only 30\% of SMEs report without explicit reference to GRI. Unlike the large companies some of the SMEs, in particular, the experienced reporters are able to fully and substantially disclose material sustainability issues in their report even though they do not follow the GRI guidelines.

\section{Status and quality of non-financial reporting}

The following section presents the results of the analysis of the non-financial reporting by companies that will be obligated to report in the future.

\subsection{Non-financial reports are still few and far between}

The analysis of non-financial information shows that the vast majority of reporting companies do not perform sepa- 


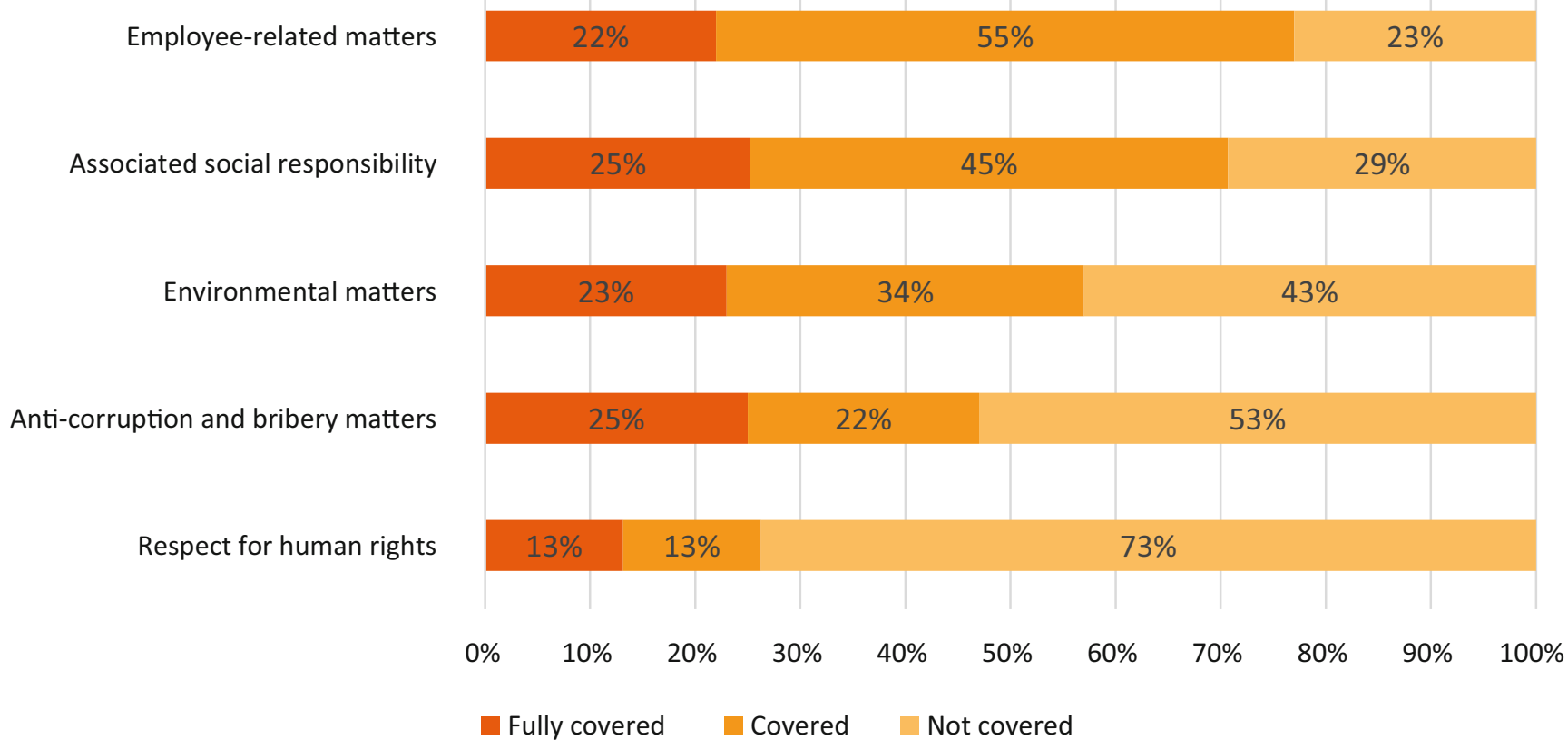

Fig. 5 Scope of reporting regarding policies, due diligence, and policy outcomes in all topic areas $(N=522)$ (Deviations from $100 \%$ are caused by rounding errors.)

rate non-financial reporting for the period under review (financial year 2016 or 2015). This study found that $63 \%$ of the evaluated reports are management reports (overwhelmingly lacking any non-financial statements), followed by sustainability reports (19\%), integrated reports (4\%), and declarations of conformity with the German Sustainability $\operatorname{Code}^{10}(1 \%)$. The category "Other" includes $13 \%$ of the evaluated reports (see Fig. 4). "Other Reports" includes all reports with non-financial content that could not clearly be assigned to one of the report formats mentioned above (e.g., formats like "sustainability brochures" and "sustainability magazines" that are substantially less detailed in comparison to sustainability reports).

\subsection{Reports still incomplete for required topics}

While a majority of the reports meet the CSR Directive Implementation Act requirements for the description of the business model, the same cannot be said for the required information on non-financial topics. Only $8 \%$ of the $522 \mathrm{com}-$ panies report comprehensively on policies, due diligence, and policy outcomes for each of the topics required under the CSR directive implementation Act. Although 24\% of the reports evaluated deal with all non-financial topics, they address at least one topic only in a very general way,

\footnotetext{
${ }^{10}$ In a declaration of conformity with the sustainability code (DNK), a company report how it meets the criteria of the DNK, or plausibly explains why it does not report a criterion (cf. German Council for Sustainable Development 2017).
}

without presenting any comprehensive policies, due diligence, or outcomes. In fact, $68 \%$ of the reports reviewed do omit policies, due diligence or the outcomes of the policies at least on one topic. Only four reports justify these omissions by commenting on respect for human rights and anti-corruption and bribery.

As shown in the cumulative view of Fig. 5, respect for human rights as well as anti-corruption and bribery matters are the two least addressed aspects in all reports. Employeerelated and social matters are addressed in just over twothirds of the reports. Specifically, employee-related matters include information on personnel structure, recruiting and development and, in some cases, occupational safety and health protection as well as other topics such as diversity or working time models. Social matters include, in particular, corporate citizenship activities (donations, sponsoring). More than half of the reports cover environmental matters, in particular, climate protection, and energy efficiency. Anti-corruption and bribery are dealt with in just under half of the reports, often with only a reference to the compliance management system without explicitly referencing corruption. Respect for human rights is addressed in about a quarter of corporate reports with frequent reference to international standards, while the implementation of corporate policies often remains rather vague.

The evaluated reports also still have significant gaps in the treatment of risks related to each topic. 57\% of companies do not cover any of their business activity related risks, while about one third are most likely to address employeerelated and another third are likely to cite environmental 
risks. The risks related to human rights and social matters are each only addressed by about $10 \%$ of companies.

Risks associated with business relationships, products, and services are discussed in even fewer reports. The percentage of reports dealing with this type of risk is less than one third. A quarter of the companies address this type of risks with relevance for environmental matters; regarding employee-related matters this type of risk is the least discussed (13\% of the reports). Overall, risks are often mentioned only indirectly, for example, by reporting very generally on approaches to risk avoidance, without addressing the specific risk and its potential effects.

\subsection{A small proportion of companies rely on reporting frameworks}

When preparing their non-financial information, 117 or $22 \%$ of the companies state that they orient on external frameworks. In this context, 103 of these companies refer to the use of GRI4 (Global Reporting Initiative 2013) and two others to the GRI standards (Global Reporting Initiative 2016). Additional frameworks mentioned include the German Sustainability Code (German Sustainable Development Council 2017), the International Integrated Reporting Framework (International Integrated Reporting Council 2013), and various industry-specific reporting standards. Similar to the ranking of sustainability reports, the GRI proves to be the most commonly used reporting framework. $11 \%$ of companies state that an external audit was performed on the reported non-financial information.

\subsection{Need for improvement at many companies}

Overall, the review of non-financial reporting shows that reports based on external frameworks such as GRI4 or German Sustainability Code are best able to meet the requirements of the CSR Directive Implementation Act. Yet, even in these cases there is still room for improvement and an even greater need exists with other forms of reporting. For example, a more consistent selection and linkage of financial and non-financial disclosures is necessary that takes the principle of materiality into account that is defined in the CSR Directive Implementation Act. This materiality concept requires disclosing that kind of information on the topics (environmental, employee-related, social matters, respect for human rights, anti-corruption and bribery matters) that gives an understanding of the business performance, the operating results, and situation of the company as well as the business operations' impacts on these topics. Room for improvement also applies to comprehensive descriptions of applied policies on individual non-financial themes (including due diligence) or the well-founded omission of infor- mation as well as a description of risks and measures to handle these risks.

\section{Discussion and conclusion}

In 2018, some German companies will be obligated to report for the first time comprehensive non-financial data for fiscal year 2017 in accordance with the CSR Directive Implementation Act. The introduction of a new reporting obligation represents a major change from the current voluntary practice. The question how this change will influence reporting practice and reporting quality can only be answered based on a comparison of reporting practice between the year 2018 and before. In preparation of this comparison, we provide an overview on reporting practice in the year 2017. Our results allow us to show trends, to develop suggestions on resulting changes and to derive questions for further research. We will build on this starting in 2018 with a new iteration of the sustainability report ranking and further analysis of reports from companies that are subject to mandatory reporting.

The analysis of non-financial information from 522 German companies shows that the vast majority of reporting companies do not perform separate non-financial reporting for the period under review (financial year 2015 or 2016). Almost two thirds of the companies publish management reports (overwhelmingly lacking any non-financial statements), followed by about one fifth that publishes sustainability reports and the remainder publishes other kinds of reports (e.g. integrated reports, declarations of conformity with the German Sustainability Code or sustainability magazines).

Looking back in review over the past year, we see that reporting, until now, still has gaps concerning some of the aspects required by the CSR Directive Implementation Act. Companies should more thoroughly describe the policies in place as well as risks and measures to handle these risks. Moreover, it is necessary to more rigorously select and link financial and non-financial information with respect to the law's materiality principle. In addition, the analysis of sustainability reports shows that there is still room for improvements. For other countries, researchers have also identified needs for an improved reporting quality (e.g. Hąbek and Wolniak 2016; Lock and Seele 2016).

The significant increase in large companies with sustainability or integrated reports observed in the 2015 ranking indicates that companies are already preparing for the mandatory non-financial reporting. Here, we probably already see an impact of the upcoming law on the number of reports. The amount of companies who publish non-financial statements or sustainability reports will definitely increase further due to the reporting mandate. Positive impacts of 
reporting mandates on the share of reporting companies have already been described for other countries (BubnaLitic 2004).

The ranking of sustainability reports of large German companies shows that new reporters among large companies often present incomplete and less meaningful reports. We observe, that most companies need a start-up time before the necessary structures, management systems and programs as well as a corresponding database are in place for good reporting. This is in line with Albertini (2014) who finds that environmental disclosure becomes more precise over time but in contrast to Lock and Seele (2016) who find no relationship between reporting experience and reporting quality. Based on our findings we assume that the introduction of a reporting mandate might in the beginning result in a decrease of overall reporting quality due to the amount of new reporters but will probably increase over time.

An essential question will be how companies define materiality in their non-financial information: Will they rely on the materiality concept of the CSR Directive Implementation Act, according to which material aspects are those that have direct impacts on the business operations? Or will they follow the GRI's understanding and also include those aspects that have direct social and ecological impacts but will be relevant for the course of business only in the mid- or long-term? We assume that companies that start reporting due to the CSR Directive Implementation Act will base their reports on a narrower understanding of materiality than experienced reporters. Moreover, they will presumably be less able to meet requirements regarding comprehensiveness and reporting quality as described e.g. by the GRI standards or our ranking criteria. We will probably observe two groups of reporters: those companies that aim at informing stakeholders about CSR-related topics and that will report based on GRI and/or on issues requested by stakeholders. On the other hand, those companies that only aim at fulfilling the requirements of the CSR Directive Implementation Act and that will consequently only provide a minimum of information. A question for further research will be under which conditions new reporters publish reports that go beyond the mere reporting duties as set by the CSR Directive Implementation Act.

Presently, it is not clear whether companies will comply with the CSR Directive Implementation Act in terms of non-financial statements in the management report or in the form of stand-alone non-financial reports. Up until now, the analysis of non-financial reporting shows that those companies that rely on GRI or the DNK disclose more detailed information on sustainability topics. Here, our results differ from Michelon et al. (2015) who find no influence of reporting practices such as stand-alone reports or the use of reporting guidance on research quality. However, we assume that a detailed disclosure can better be realized in stand-alone reports. Since non-financial statements have to provide legal certainty and thus have to fulfil high standards regarding data quality and external assurance, companies will probably include less information in non-financial statements than in stand-alone reports. Presumably, long standing reporters will continue to publish stand-alone sustainability reports in addition to an obligatory non-financial statement. This allows them to provide information for different stakeholder groups.

Looking at the results of the two studies presented allows us to derive a few practical implications. Companies that will publish their first report due to the reporting obligation should use established reporting standards such as the GRI guidelines. By applying these guidelines, they lay the foundation for enlarging their reporting to other aspects than those set by the CSR Directive Implementation Act. Moreover, it is important that reporting corresponds with structures, management systems and programs as well as a necessary database in order to offer meaningful information. Companies should thus put emphasis on developing structures, systems and programs. The non-financial statement is an additional element in the broad variety of formats and media companies already use for publishing sustainability information. If companies offer different publications such as non-financial statements, sustainability reports and other target group specific publications, a clear structure and targeted links between the publications are necessary for the different formats.

Acknowledgements The studies presented in this article were funded by the German Federal Ministry of Labor and Social Affairs. We are grateful to our former colleague Dr. Gerd Scholl and our project partner future e. V.- - verantwortung unternehmen, especially to Dr. Udo Westermann. We moreover thank two anonymous reviewers for their supportive feedback that helped us to improve the text.

Conflict of interest E. Hoffmann, C. Dietsche and C. Hobelsberger declare that they have no competing interests.

Open Access This article is distributed under the terms of the Creative Commons Attribution 4.0 International License (http:// creativecommons.org/licenses/by/4.0/), which permits unrestricted use, distribution, and reproduction in any medium, provided you give appropriate credit to the original author(s) and the source, provide a link to the Creative Commons license, and indicate if changes were made.

\section{References}

Albertini E (2014) A Descriptive Analysis of Environmental Disclosure: A Longitudinal Study of French Companies. J Bus Ethics 121(2):233-254. https://doi.org/10.1007/s10551-013-1698-y

Boodoo MU (2016) Does Mandatory CSR Reporting Regulation Lead to Improved Corporate Social Performance? Evidence from. SSRN Electronic Journal, India https://doi.org/10.2139/ ssrn. 2823956

Bouten L, Everaert P, Van Liedekerke L, De Moor L, Christiaens J (2011) Corporate social responsibility reporting: A compre- 
hensive picture? Accounting. Forum Fam Plan West Hemisph 35(3):187-204. https://doi.org/10.1016/j.accfor.2011.06.007

Bubna-Litic K (2004) Mandatory corporate environmental reporting: Does it really work? Keeping Good. Companies 56(10):615-619

Bundesministerium der Justiz und für Verbraucherschutz (Ed, 2018) Bundesanzeiger. Questions and Answers. https://www.bundes anzeiger.de/ebanzwww/wexsservlet?global_data.language=en\& session. sessionid=3987f2c8daebdb8bc1b881b9fda41d03\&page. navid=gotolastpage. Accessed December 20, 2017

Chen Y-C, Hung M, Wang Y (2018) The effect of mandatory CSR disclosure on firm profitability and social externalities: Evidence from China. J Account Econ 65(1):169-190. https://doi.org/10. 1016/j.jacceco.2017.11.009

Daub C-H (2007) Assessing the quality of sustainability reporting: an alternative methodological approach. J Clean Prod 15(1):75-85. https://doi.org/10.1016/j.jclepro.2005.08.013

Deutscher Bundestag (2017) Gesetz zur Stärkung der nichtfinanziellen Berichterstattung der Unternehmen in ihren Lage- und Konzernlageberichten (CSR-Richtlinie-Umsetzungsgesetz) dated April 11, 2017, Bundesgesetzblatt Jahrgang 2017 Teil I Nr. 20, ausgegeben zu Bonn on April 18, 2017, pp. 802-814

EU Commission (Ed, 2014) Directive 2014/95/EU of the European Parliament and the Council of 22 October 2014 amending Directive 2013/34/EU as regards disclosure of non-financial and diversity information by certain large undertakings and groups. ABIEU L, 330, pp. 1-9

German Council for Sustainable Development (Ed, 2017) The Sustainability Code. Benchmarking sustainable business $\left(4^{\text {th }}\right.$ revised edition). https://www.deutscher-nachhaltigkeitskodex.de/fileadmin/ user_upload/dnk/dok/kodex/The_SustainabilityCode_2017.pdf. Accessed December 20, 2017

Global Compact UN (Ed) (2012) Basic Guide. Communication on Progress. https://www.unglobalcompact.org/docs/communication _on_progress/Tools_and_Publications/COP_Basic_Guide.pdf. Accessed 20 Dec 2017

Global Reporting Initiative (Ed, 2000) Sustainability Reporting Guidelines. https://www.globalreporting.org/resourcelibrary/ G3.1-Guidelines-Incl-Technical-Protocol.pdf. Accessed 20 Dec 2017

Global Reporting Initiative (Ed, 2013) G4 Sustainability Reporting Guidelines. Reporting Principles and Standard Disclosures. https://www.globalreporting.org/resourcelibrary/GRIG4-Part1Reporting-Principles-and-Standard-Disclosures.pdf. Accessed 20 Dec 2017

Global Reporting Initiative (Ed, 2016) Consolidated Set of GRI Sustainability Reporting Standards. https://www.globalreporting.org/ standards/gri-standards-download-center/?g=0cee5554-57194d20-bbde-f96ea02ec15a. Accessed 20 Dec 2017

Hąbek P, Wolniak R (2016) Assessing the quality of corporate social responsibility reports: the case of reporting practices in selected European Union member states. Qual Quant 50(1):399-420. https://doi.org/10.1007/s11135-014-0155-z

Hahn R, Kühnen M (2013) Determinants of sustainability reporting: a review of results, trends, theory, and opportunities in an expanding field of research. J Clean Prod 59:5-21. https://doi.org/ 10.1016/j.jclepro.2013.07.005

Hess D (2007) Social Reporting and New Governance Regulation: The Prospects of Achieving Corporate Accountability through Transparency. Bus Ethics Q 17(3):453-476. https://doi.org/10. 5840/beq200717348

International Integrated Reporting Council (Ed, 2013) The International IR Framework. https://integratedreporting.org/wp-content/ uploads/2013/12/13-12-08-THE-INTERNATIONAL-IR-FRAM EWORK-2-1.pdf. Accessed 20 Dec 2017

Ioannou I, Serafeim G (2011) The Consequences of Mandatory Corporate Sustainability Reporting. SSRN Electron J. https://doi.org/ $10.2139 /$ ssrn. 1799589
IÖW (Institut für ökologische Wirtschaftsforschung) und future (Eds, 2016) Nachhaltigkeitsberichterstattung in Deutschland. Ergebnisse und Trends im Ranking der Nachhaltigkeitsberichte 2015, Berlin/Münster. http://www.ranking-nachhaltigkeitsberichte.de/ data/ranking/user_upload/2015/Ranking_Nachhaltigkeitsberichte _2015_Ergebnisbericht.pdf. Accessed January 3, 2018

IÖW (Institut für ökologische Wirtschaftsforschung) und future (Eds, 2015a) Anforderungen an die Nachhaltigkeitsberichterstattung. Kriterien und Bewertungsmethode im IÖW/future-Ranking 2015, Berlin/Münster (aktualisierte Fassung von. http://www.rankingnachhaltigkeitsberichte.de/data/ranking/user_upload/2015/I\%C3 \%96W-future-Ranking_2015_Bewertungskriterien_Gro\%C3 \%9Funternehmen.pdf. Accessed 20 Dec 2017

IÖW (Institut für ökologische Wirtschaftsforschung) und future (Eds, 2015b) Anforderungen an die Nachhaltigkeitsberichterstattung von KMU: Kriterien und Bewertungsmethode im IÖW/ future-Ranking 2015, Berlin/Münster (aktualisierte Fassung von. http://www.ranking-nachhaltigkeitsberich-te.de/data/ranking/ user_upload/2015/I\%C3\%96W_future_Ranking_2015_Bewer tungskiriterien_KMU.pdf. Accessed 20 Dec 2017

IÖW (Institut für ökologische Wirtschaftsforschung) und future (Eds, 2018) Deutsche Unternehmen vor der CSR-Berichtspflicht - Monitoring zur nichtfinanziellen Berichterstattung, Berlin/ Münster. https://www.ranking-nachhaltigkeitsberichte.de/data/ ranking/user_upload/2018/Deutsche_Unternehmen_vor_der_ CSR-Berichtspflicht_18.pdf. Accessed 2001

IÖW (Institut für ökologische Wirtschaftsforschung) und future (Eds, 2012a) Das IÖW/future-Ranking der Nachhaltigkeitsberichte 2011: Ergebnisse und Trends, Berlin/Münster. http:// www.ranking-nachhaltigkeitsberichte.de/data/ranking/user_uplo ad/pdf/IOEW-future-Ranking_2011_Grossunternehmen_Ergeb nisbericht.pdf. Accessed 20 Dec 2017

IÖW (Institut für ökologische Wirtschaftsforschung) und future (Eds, 2012b) IÖW/future-Ranking der Nachhaltigkeitsberichte deutscher KMU: Ergebnisse und Trends, Berlin/Münster. http:// www.ranking-nachhaltigkeitsberichte.de/data/ranking/user_uplo ad/pdf/IOEW-future-Ranking_2011_KMU_Ergebnisbericht.pdf. Accessed 20 Dec 2017

IÖW (Institut für ökologische Wirtschaftsforschung) und future (Eds, 2017) Das Ranking der Nachhaltigkeitsberichte. Ergebnisse, Trends und Branchenauswertungen im IÖW/future-Ranking 2015, Berlin/Münster. http://www.ranking-nachhaltigkeitsberich te.de/data/ranking/user_upload/2015/Ranking_Nachhaltigkeitsbe richte_2015_Ergebnisbericht_mit_Branchenauswertung.pdf. Accessed 20 Dec 2017

Kluge N, Sick S (2016) Geheimwirtschaft bei Transparenz zum gesellschaftlichen Engagement? Zum Kreis der vom CSR Directive Implementation Act potentiell betroffenen Unternehmen. MBF-Report Nr. 27, 11.2016, Hans-Böckler-Stiftung, Düsseldorf

Lock I, Seele P (2016) The credibility of CSR (corporate social responsibility) reports in Europe. Evidence from a quantitative content analysis in 11 countries. J Clean Prod 122:186-200. https://doi. org/10.1016/j.jclepro.2016.02.060

Michelon G, Pilonato S, Ricceri F (2015) CSR reporting practices and the quality of disclosure: An empirical analysis. Crit Perspect Account 33:59-78. https://doi.org/10.1016/j.cpa.2014.10.003

Morhardt JE (2001) Scoring Corporate Environmental Reports for Comprehensiveness: A Comparison of Three Systems. Environ Manage 27(6):881-892. https://doi.org/10.1007/s002670010196

Romolini A, Fissi S, Gori E (2014) Scoring CSR Reporting in Listed Companies-Evidence from Italian Best Practices: Scoring CSR Reporting in Listed Companies. Evidence from Italy. Corp Soc Responsib Environ Manag 21(2):65-81. https://doi.org/10.1002/ csr.1299

Skouloudis A, Evangelinos K, Kourmousis F (2009) Development of an Evaluation Methodology for Triple Bottom Line Reports 
Using International Standards on Reporting. Environ Manage 44(2):298-311. https://doi.org/10.1007/s00267-009-9305-9

Springer Gabler Verlag (Ed) (n.d.) Gabler Wirtschaftslexikon, Stichwort: Lagebericht. http://wirtschaftslexikon.gabler.de/Archiv/ 58187/lagebericht-v10.html. Accessed 3 Jan 2018
Verein zur Förderung der Gemeinwohl-Ökonomie (Ed, 2015) Handbuch zur Gemeinwohl-Bilanz. Version 4.1. http://berlin.gwoe.net/ files/2011/12/20151218_HandbuchBilanz_v.4.1_cc_release.pdf. Accessed 3 Jan 2018 